\title{
STUDI FENOMENOLOGI PROMOSI KESEHATAN DALAM PROGRAM ASI EKSKLUSIF DI KOTA BUKITTINGGI
}

\author{
Nila Eza Fitria \\ Magister Ilmu Kesehatan Masyarakat STIKes Fort De Kock Bukittinggi \\ e-mail: nila.ezafitria@gmail.com
}

Submitted: 29-11-2017, Reviewer: 03-01-2018, Accepted: 15-08-2019

\begin{abstract}
The successful implementation of exclusive breastfeeding program in Indonesia has not been as expected. Attention to health workers as one of the spearheads of exclusive breastfeeding program success is needed to improve health promotion. The purpose of this study is to explore the experience of health promotion officers of exclusive ASI programs. This research is a type of qualitative research with descriptive phenomenology approach. The informants consisted of 7 main informants (exclusive ASI promotion officer) and 8 supporting informants ( 2 health service officers and 6 mothers with children under five). Data collection techniques were conducted with in-depth interviews. The results of the research show that the theme of exclusive breastfeeding promotion officer who served in each puskesmas of Bukittinggi City mamahami health promotion exclusive breastfeeding program. There is no written policy from the Bukittinggi Municipal Government, still referring to the Decree of the Minister of Manpower of 2004 on exclusive breastfeeding. Officers have tried to exclusively promote exclusive breastfeeding. Official barriers in exclusive breastfeeding promotion efforts lack written policies, lack of cross-program and crosssector cooperation and low awareness of the community. The implications of this research on public health science as the basis of information for public health officers on the description of the implementation of exclusive ASI programs. It takes the cooperation of all parties to support the success of exclusive breastfeeding.
\end{abstract}

Keywords: Experience, Health Officer, Health Promotion, Exclusive breastfeeding

\begin{abstract}
ABSTRAK
Keberhasilan pelaksanaan program ASI eksklusif di Indonesia belum sesuai harapan. Perhatian terhadap petugas kesehatan sebagai salah satu ujung tombak keberhasilan program ASI eksklusif diperlukan untuk meningkatkan kembali promosi kesehatan. Tujuan dari penelitian ini untuk mengeksplorasi pengalaman petugas promosi kesehatan program ASI eksklusif. Penelitian ini merupakan jenis penelitian kualitatif dengan pendekatan fenomenologi deskriptif. Informan terdiri dari 7 informan utama (petugas promkes ASI eksklusif) dan 8 informan pendukung (2 petugas dinas kesehatan dan 6 orang ibu yang memiliki balita). Teknik pengumpulan data dilakukan dengan wawancara. Hasil penelitian didapatkan tema yang menunjukkan petugas promosi ASI eksklusif yang bertugas di masing-masing puskesmas Kota Bukittinggi mamahami promosi kesehatan program ASI eksklusif. Belum ada kebijakan secara tertulis dari pemerintah Kota Bukittinggi, masih mengacu ke SK MenKes tahun 2004 tentang ASI eksklusif. Petugas sudah berusaha melakukan promosi ASI eksklusif secara maksimal. Hambatan petugas dalam usaha promosi ASI eksklusif belum adanya kebijakan secara tertulis, masih kurangnya kerjasama lintas program dan lintas sektor serta rendahnya kesadaran dari masyarakat. Implikasi penelitian ini terhadap ilmu kesehatan masyarakat sebagai dasar informasi bagi petugas kesehatan masyarakat mengenai gambaran pelaksanaan program ASI eksklusif. Diperlukan kerjasama semua pihak untuk mendukung keberhasilan pemberian ASI esksklusif.
\end{abstract}

Kata kunci : Pengalaman, Petugas kesehatan, Pomosi Kesehatan, ASI ekslusif 


\section{PENDAHULUAN}

ASI eksklusif adalah ASI yang diberikan pada bayi sampai berusia 6 bulan tanpa tambahan makanan dan minuman, kecuali obat dan vitamin. Bayi yang mendapat ASI eksklusif adalah bayi yang hanya mendapat ASI saja sejak lahir sampai usia 6 bulan disuatu wilayah kerja pada kurun waktu tertentu (Roesli Utami, 2009). Pemberian ASI merupakan hal penting pada bayi terutama pemberian ASI awal (kolostrum) karena kaya dengan antibody yang mempunyai efek terhadap penurunan resiko kematian. ASI berguna untuk perkembangan sensorik dan kognitif, mencegah bayi terserang penyakit infeksi dan kronis. ASI terutama ASI eksklusif menurunkan kematian bayi dan kejadian sakit pada anak yaitu diare atau ISPA, dan membantu kesembuhan dari penyakit ( Fikawati, 2010 ).

Pemberian ASI yang eksklusif dan berkelanjutan telah ditetapkan sebagai salah satu intervensi penting dalam pengurangan kematian neonatal dan balita. Pemberian ASI eksklusif pada 6 bulan pertama kehidupan meningkatkan pertumbuhan, kesehatan dan status pertahanan bayi baru lahir dan ini adalah salah satu bentuk obat pencegahan alami yang terbaik. Telah diperkirakan bahwa ASI eksklusif mengurangi angka kematian balita sampai 13\% pada Negara dengan penghasilan rendah (Dachew, 2014).

Meskipun telah diketahui banyaknya manfaat dari pemberian ASI, namun dibuktikan bahwa ada beberapa faktor menghalangi keoptimalan praktik pemberian ASI eksklusif. Beberapa diantara faktor penghambat tersebut adalah pekerjaan ibu, praktik rumah sakit yang tidak bersahabat, iklan susu formula, ketidaktahuan, tekanan keluarga dan penyakit ibu, dll. Pengetahuan dan sikap tenaga kesehatan dalam hal ini bisa memberikan dampak besar terhadap pemberian ASI eksklusif tersebut ( Utoo, Ochejele, Obulu \& Utoo, 2012).

Untuk mendukung pemberian ASI eksklusif di Indonesia pada tahun 1990 pemerintah mencangangkan Gerakan Nasional Peningkatan Pemberian ASI (GNPP-ASI). Selain undang-undang N0.23 tahun 2002 tentang perlindungan anak pasal 22 . Keputusan Menteri Kesehatan Republik Indonesia No. 450/MENKES/IV/2004 tanggal 7 April 2004 berisi tentang Pemberian ASI secara eksklusif pada bayi di Indonesia selama 6 bulan (Depkes RI, 2007).

Persentase pemberian ASI eksklusif pada bayi 0-6 bulan di Indonesia pada tahun 2013 yaitu sebesar $54,3 \%$ sedikit meningkat dibandingkan dengan tahun 2012 yaitu 48,6\% (Kemenkes RI, 2014). Walaupun sudah mengalami peningkatan, angka tersebut jelas masih jauh dari target nasional yang diharapkan dalam mencapai tujuan peningkatan pemberian ASI eksklusif yang seharusnya mencapai angka $80 \%$. Sementara itu untuk provinsi Sumatera Barat persentase pemberian ASI eksklusif pada bayi 0-6 bulan pada tahun 2013 sebesar 68,9\% (Kemenkes RI, 2014).

Berdasarkan data yang diperoleh dari Dinas Kesehatan Kota Bukittinggi pencapaian ASI Eksklusif di kota Bukittinggi masih dibawah target program pemerintah. 
Dari 7 Puskesmas yang ada di Kota Bukittinggi hanya 1 Puskesmas yang pencapaiannya diatas $80 \%$, sedangkan 6 puskesmas yang lain masih rendah yaitu rata-rata $68 \%$. Angka ini masih rendah mengingat target pemerintah program ASI eksklusif $80 \%$ (Dinkes Kota Bukitinggi).

Berdasarkan survey pendahuluan yang dilakukan melalui wawancara dengan bagian Gizi Dinas Kesehatan Kota Bukittinggi diperoleh informasi bahwa kurang optimalnya suatu proses pelaksanaan program ASI eksklusif yang dilakukan karena kurangnya koordinasi antar program KIA dan program Gizi, keterbatasan sumber daya yang ada, diantaranya : Terbatasnya anggaran biaya untuk program ASI eksklusif, terbatasnya kemampuan dan keterampilan sumber daya yang ada dalam hal ini bidan sebagai manajemen laktasi, kurangnya fasilitas/sarana pojok laktasi dan jika dilihat dari aspek manajemennya kurang dilaksanakan secara optimal sesuai proses manajemen yang seharusnya diterapkan oleh petugas kesehatan.

Melihat berbagai fenomena diatas terkait sikap dan praktik pemberian ASI eksklusif, penulis tertarik untuk mengeksplorasi lebih dalam bagaimana pengalaman petugas kesehatan yang berperan sebagai advokat, edukator dan role model terhadap ketidakberhasilan mereka dalam program ASI eksklusif. Penelitian ini akan dilakukan dengan pendekatan fenomenologi karena masih sedikit penelitian terkait ketidakberhasilan pemberian ASI eksklusif dengan desain Kualitatif. Selain itu dengan menggunakan pendekatan fenomenologi ini diharapkan akan diperoleh informasi baru yang lebih banyak secara komprehensif dan mendalam terkait fenomena ketidakberhasilan ibu-ibu menyusui dalam pemberian ASI eksklusif.

\section{METODE PENELITIAN}

Penelitian ini menggunakan jenis penelitian kualitatif dengan pendekatan fenomenologi. Penelitian ini dilakukan pada bulan September 2017 di wilayahDinasKesehatan Kota Bukittinggi. Informan penelitian adalah informanutama 7 orang petugaspelaksanapromosi program ASI eksklusif (bagiangizi) di masing-masingpuskesmas Kota Bukittinggi dan Informan pendukung satu orang kepala dinas kesehatan Kota Bukittinggi, satu orang pemegang promkes di dinas kesehatan Kota Bukittinggi dan 6 orang ibu-ibu yang mempunyai balita yang memberikan ASI eksklusif dan tidak eksklusif yang memenuhi kriteria inklusi. Data pada penelitian ini diperoleh dari catatan, laporan dan rekapitulasi data yang ada di dinas kesehatan Kota Bukittinggi yang berhubungan dengan penelitian dan wawancara mendalam serta observasi.

\section{HASIL DAN PEMBAHASAN 1. Komponen Input}

Komponen input terdiri dari SDM, Kebijakan, Dana dan Sarana. Pelaksaanaan promosi program ASI eksklusif memerlukan keterlibatan banyak pihak, khususnya dalam promosi ASI eksklusif. Keberhasilan promosi ASI eksklusif ditunjang pula oleh ketersediaan fasilitas di puskesmas. SDM untuk sudah paham mengenai promosi program ASI eksklusif tapi masih terbatas jumlahnya di masing-masing puskesmas Kota Bukittinggi. 
Kebijakan secara tertulis mengenai ASI eksklusif dari pemerintah Kota Bukittingggi belum ada, kebijakan yang berjalan mengacu ke SK MenKes No 450/MENKES/SK/IV/2004 tanggal 7 April tahun 2004 yang merekomendasikan menyusui secara eksklusif (exclusive breastfeeding) sejak lahir sampai 6 bulan hidup anak. Dana khusus untuk kegiatan promosi program ASI eksklusif belum ada tapi melekat ke kegiatan yang lain dan juga ada diambilkan dari dana BOK ( Bantuan Operasional Kesehatan) serta sarana untuk promosi program ASI eksklusif masih terbatas seperti alat peraga masih kurang dan juga perlu adanya media untuk penayangan slide dan video. Berdasarkan hasil pengamatan, ditemukan bahwa pada saat kegiatan posyandu petugas yang turun kelapangan sangat kurang dan minimnya media / fasilitas promosi ASI eksklusif. Petugas menyampaikan penyuluhan kurang fokus karena banyaknya program dan kurangnya tenaga pada saat dilapangan serta kurangnya koordinasi antara Bidan dan petugas Gizi. Hanya beberapa puskesmas yang menggunakan alat bantu pada saat posyandu dalam penyuluhan atau konseling ASI eksklusif.

\section{Tabel 1. Rangkuman Hasil Penelitian Kualitatif tantang Komponen Input dalam Promosi Program ASI Eksklusif.}

\begin{tabular}{ll}
\hline Variabel & Hasil Penelitian \\
\hline Sumber Daya Manusia (SDM) & $\begin{array}{l}\text { Latar belakang pendidikan petugas D.III Gizi } \\
\text { dan S1 Gizi, Petugas promosi pengelola } \\
\text { program ASI eksklusif paham dengan promosi } \\
\text { program ASI eksklusif }\end{array}$ \\
Belum ada kebijakan khusus ASI eksklusif \\
secara tertulis dari pemerintah Kota Bukittinggi \\
Dana dan Sarana & $\begin{array}{l}\text { Belum terakomodir alokasi dana khusus serta } \\
\text { keterbatasan sarana prasarana }\end{array}$ \\
& $\begin{array}{l}\text { Media promosi berupa leaflet dan poster dan } \\
\text { masih perlu penambahan sarana media promosi }\end{array}$ \\
& $\begin{array}{l}\text { Belum semua puskesmas yang mempunyai alat } \\
\text { peraga atau alat bantu dalam promosi atau } \\
\text { konseling ASI eksklusif. }\end{array}$
\end{tabular}


2. Komponen Proses

Komponen proses yang terdiri dari upaya yang telah dilakukan petugas untuk promosi program ASI eksklusif, Hambatan petugas dan kebutuhan petugas promosi program ASI eksklusif didapatkan dari hasil penelitian bahwa upaya petugas dalam promosi ASI eksklusif selama ini adalah penyuluhan, penyuluhan yang dilakukan hanya menganjurkan pada masyarakat. Hambatan petugas dalam promosi masih kurang kerjasama antara lintas program dan lintas sektor dan juga sasaran. Kebutuhan petugas promosi program ASI eksklusif penambahan sarana media promosi seperti alat peraga, dan kerjasama semua pihak.

Berdasarkan hasil pengamatan peneliti, upaya yang dilakukan oleh petugas promosi pengelola program ASI eksklusif adalah penyuluhan kepada ibu-ibu hamil atau ibu yang mempunyai balita dan konseling pada saat ada kegiatan posyandu, tapi tidak fokus penyampian ASI saja. Mereka berargumen bahwa kurangnya tenaga serta banyaknya program yang harus dijalankan menjadi kendala pelaksanaan promosi program ASI eksklusif.

\section{Tabel 2. Rangkuman Hasil Penelitian Kualitatif Tentang Komponen Proses Promosi Program ASI Eksklusif.}

\begin{tabular}{ll}
\hline Variabel & Hasil \\
\hline Upaya Petugas promosi program & Penyuluhan \\
Kerjasama lintas program dan lintas sektor & $\begin{array}{l}\text { Inovasi baru membentuk wadah tim motivator ASI } \\
\text { dan kelompok-kelompok pendukung ASI }\end{array}$ \\
Belum ada kebijakan secara tertulis mengenai ASI \\
eksklusif dari pemerintah Kota Bukittinggi \\
Kerjasama masih dirasa kurang \\
Rendahnya kesadaran dari sasaran \\
Kerjasama semua pihak terkait \\
Kebijakan dari pemerintah Kota Bukittinggi secara \\
tertulis \\
Pembinaan berkesinambungan dari Puskesmas dan \\
Dinas Kesehatan \\
Kerjasama semua pihak \\
\hline
\end{tabular}




\section{Komponen Out Put}

Komponen output dalam promosi program ASI eksklusif di Kota Bukittinggi yang diteliti dimaksudkan sebagai bahan croschek pelaksanaan promosi program ASI eksklusif. Penelitian mendalam tidak dilakukan sampai komponen output. Komponen output diperoleh dari hasil wawancara dengan informan utama dan informan pendukung. Hasil yang didapatkan tentang evaluasi promosi program ASI eksklusif bahwa informasi mengenai program ASI eksklusif belum merata di masyarakat.
Hal ini bisa dibuktikan dengan masih rendahnya hasil cakupan ASI eksklusif di Kota Bukittinggi. Petugas promosi kesehatan pengelola program ASI eksklusif di masing-masing puskesmas menyampaikan bahwa pernah dilakukan evaluasi hanya kepada pihak kader kesehatan dan belum pernah evaluasi lansung ke masyarakat atau ibu-ibu yang mempunyai bayi balita mengenai penggalakkan ASI eksklusif. Dan sebagian petugas mengatakan evaluasi tentang program ASI eksklusif dilakukan per enam bulan setelah tahu capaiannya.

\section{Tabel 3. Rangkuman Hasil Penelitian Kualitatif tentang Komponen Output dalam Promosi Program ASI Eksklusif di Kota Bukittinggi}

\begin{tabular}{ll}
\hline Variabel & \multicolumn{1}{c}{ Hasil } \\
\hline Output & $\begin{array}{l}\text { Promosi ASI eksklusif belum merata sampai di } \\
\text { masyarakat } \\
\text { Pencapaian ASI eksklusif belum sesuai target program } \\
\text { pemerintah }\end{array}$
\end{tabular}

\section{SIMPULAN}

Hasil penelitian ini didapatkan tema yaitu pemahaman petugas (SDM) mengenai makna dan arti promosi kesehatan program ASI eksklusif, Kebijakan program ASI eksklusif, Dana dan sarana promosi ASI eksklusif, Upaya petugas kesehatan terkait pelaksanaan program ASI eksklusif, hambatan promosi kesehatan ASI eksklusif, serta kebutuhan promosi kesehatan ASI esksklusif. Berikut uraiannya :
Petugas promosi kesehatan pengelola program ASI eksklusif di masingmasing puskesmas Kota Bukittinggi sudah memahami arti dan makna promosi kesehatan program ASI eksklusif untuk masyarakat.

Belum ada kebijakan khusus secara tertulis dari Pemerintah Kota Bukittinggi terkait program ASI eksklusif, tetapi bentuk dukungan pemerintah mengenai program ASI sudah ada. Kebijakan mengacu pada SK MenKes No 450/MENKES/SK/IV/2004 tanggal 7 April tahun 2004. 
Keterbatasan dana untuk promosi program ASI eksklusif. Pedistribusian dana belum terprogram dengan baik begitu juga sarana untuk promosi masih perlu penambahan media promosi.

Upaya yang dilakukan petugas terkait pelaksanaan promosi kesehatan program ASI eksklusif penyuluhan tentang ASI. Bentuk pembinaan dari Dinas Kesehatan Kota Bukittinggi meningkatkan upaya promosi kesehatan program ASI eksklusif ini dengan mengadakan pelatihan untuk petugas sehingga terbentuk tim motivator ASI dan kelompok-kelompok pendukung ASI.

Hambatan petugas dalam pelaksanaan promosi kesehatan program ASI eksklusif banyaknya program atau kegiatan yang lain yang harus dikerjakan membuat petugas kurang fokus untuk penyampaian informasi ke masyarakat mengenai ASI eksklusif ini. Kerjasama masih kurang baik lintas program maupun lintas sektor dan juga sasaran ASI eksklusif itu sendiri.

Kebutuhan petugas kesehatan terkait upaya promosi kesehatan mengenai program ASI eksklusif yakni kebijakan tertulis dan meningkatkan upaya pemberdayaan masyarakat tentang ASI eksklusif. Kebutuhan yang lainnya terkait upaya promosi kesehatan ASI eksklusif ini kerjasama semua pihak lintas program, semua tenaga kesehatan dan lintas sektor, pembinaan dari dinas kesehatan khususnya mengenai pelatihanpelatihan untuk petugas dan kader kesehatan serta terus adanya inovasiinovasi dalam promosi ASI eksklusif untuk peningkatan capaian program ASI eksklusif ini di Kota Bukitttinggi.

Sebagai petugas promosi kesehatan pengetahuan petugas harus terus ditingkatkan melalui informasi terbaru dengan pelatihan sehingga dapat muncul inovasi-inovasi kreatif terkait promosi ASI eksklusif dengan metode penyuluhan akan lebih baik lagi dan menarik dibantu dengan media promosi kesehatan agar informasi yang diberikan dapat tersampaikan dengan lebih baik dan agar masyarakat bisa termotivasi dan memiliki prinsip yang kuat untuk melakukan program ASI eksklusif.

\section{DAFTAR PUSTAKA}

Abdullah, G. I (2012). Determinan pemberian ASI eksklusif pada ibu bekerja di kementrian kesehatan RI. Tahun 2012. Tesis Fakultas Ilmu Kesehatan Masyarakat Universitas Indonesia.

Assosiasi Ibu menyusui Indonesia. (13 juni 2013). Berita tenaga kesehatan Indonesia perlu sosialisasi kebijakan menyusui. Diakses pada tanggal 26 April 2017 dari aimi-asi.org/tenagakesehatan-indonesia-perlusosialisasi-kebijakan-menyusui/.

Budiasih,Kun (2008) Pentingnya ASI Eksklusif untuk Bayi 0-6 Bulan. Jakarta : Harapan 
Bungin, Burhan (2010) Penelitian Kualitatif. Jakarta : Kencana Prenada Media Group.

Dachew, B.A \&Biffu, BB (2014) Breasfeeding Practice and associated factor among female nurse and midwives at north $\mathrm{G}$ ondar zone, northwest Ethiopia : A Cross - Sectional institusion based study, International Breasfeeding Journal, 9(11)1-7.

Depertemen Kesehatan RI, (2005)

Direktorat Bina Gizi Masyarakat, Direktorat Jenderal Bina Kesehatan Masyarakat.. Manajemen Laktasi. Jakarta.

Depertemen Kesehatan. (2007) Manajemen Laktasi, Panduan Bagi Bidan dan Petugas Kesehatan di Puskesmas, Dit.Gizi Masyarakat. Jakarta. Depkes RI

Depertemen Kesehatan. (2009) Profil Kesehatan Indonesia 2008. Jakarta : Depertemen Kesehatan Republik Indonesia.

Depertemen Kesehatan. (2012) Strategi Nasional Peningkatan Pemberian Air Susu Ibu sampai tahun 2005. Jakarta:Depkes RI

Dinas Kesehatan Kota Bukittinggi. (2016). Laporan tahunan 2015 edisi 2016

Fikawati \& Syafiq (2010). Kajian Implementasi dan Kebijakan Air Susu Ibu Eksklusif dan Inisiasi Menyusui Dini di Indonesia. Jurnal Kesehatan Masyarakat Nasional. Vol.14, No.1

Gladzah, N.D (2013) Challenges of eksklusif breasfeeding among female health workers in two hospital in Accra. International Journal of Nursing Midwifery. 50(3):272-82

Hadiwijono, Harun.(2012) Sari sejarah filsafat Barat 2. Yogyakarta : Kanisius.

Hamid, Farida dkk. (2014). Survey data dasar pengembangan Model Pelayanan Kesehatan Maternal di Kotamadya Tanggerang Selatan tahun 2010. Jakarta : Lembaga penelitian UIN Syarif Hidayatullah.

Hasrimayana.(2009) Hubungan antara sikap ibu dengan pemberian ASI ekslusif diwilayah kerja Puskesmas Kedawang II Sragen.

InfoDATIN, 2014. Program ASI Eksklusif di Indonesia.

Kusnanto. Hari.(2013) Metodologi Kualitatif dalam Riset Kesehatan. Yogyakarta

Lestari, D. (2014) Faktor Ibu Bayi Yang Berhubungan Dengan Pemberian ASI Eksklusif (Analisa Survey Demografi Kesehatan Indonesia) Tesis FKM -UI

Manuaba, Ida Bagus Gde. (2011) Kapita Selekta Penatalaksanaan rutin Obstetri, Ginekologi dan $K B$. Jakarta : Penerbit buku Kedokteran EGC

Moleong. 2013 . Metodologi Penelitian Kualitatif. Bandung: Rosdakarya.

Murtiyarini, (2014) Evaluasi Pelaksanaan Konseling Menyusui. Jurnal Kesehatan Masyarakat Nasional Vol. 9, No. 1 
Notoadmodjo, $\quad$ Soekidjo.(2007)

Promosi Kesehatan dan Ilmu

Perilaku. Jakarta : Rineka Cipta

2007.

Pendidikan dan Perilaku

kesehatan. Jakarta : Rineka Cipta.

2013.

Promosi Kesehatan Global.

Jakarta : Rineka Cipta.

Nuraini \& Julia ( 2013 ) Sampel Susu

Formula dan Praktik Pemberian

Air Susu Ibu Eksklusif. Jurnal

Kesehatan Masyarakat Nasional

Vol.7, No.12

Nurpelita (2015). Faktor-faktor yang berhubungan dengan Pemberian ASI Eksklusif di Wilayah Kerja Puskesmas Buatan Siak. Tesis FKM-UI

Nursalam. (2009) Konsep dan Penerapan Metodologi

Penelitian Ilmu Keperawatan. Jakarta : Salemba Medika

Prastowo, Andi.(2010) Menguasai teknik-teknik Koleksi Data Penelitian Kualitatif. Jogjakarta : DIVA.Press

Purwanti, S,H,(2004). Konsep Penerapan ASI eksklusif. Jakarta : EGC

Roesli, Utami, (2004). Buku Saku Gizi Bayi. Jakarta: EGC

(2004) Konsep

Penerapan ASI ekslusif . Jakarta :EGC. .(2009) Mengenal ASI ekslusif seri 1 . Jakarta : Niaga Swadaya.

Sadoh, A.E., Sadoh, W.E \& Oniyelu, P. (2011) Breasfeeding practice among medical women in
Nigeria,. Nigerian Medical Journal : Journal of the Nigerian Medical Association. 52(1).7-12

Saryono, (2013) Metodologi Penelitian Kualitatif dan Kuantitatif Dalam Bidang Kesehatan. Nuha Medika

Soehardjo. 2007. Pemberian makanan pada bayi dan anak. Yogyakarta : Kanisius.

Soetjiningsih, 2012. ASI Petunjuk untuk Tenaga Kesehatan. Jakarta: EGC

Sugiyono.(2009) Metode Penelitian Kuantitatif Kualitatif dan $R \& D$ Bandung : Alfabeta

Taufik, M.(2010). Prinsip-prinsip Promosi kesehatan dalam bidang Keperawatan. Bandung : Infomedika

Taveras EM, Capra AM, Braverman PA. (2011). Clinician Support and Psychosocial risk factors associated with breasfeeding Discountinuation. International of Nursing Midwifery. Vol.3 $\mathrm{No}(8): 109-17$

Undang-undang Republik Indonesia tentang kesehatan nomor 36.2009

Utoo, B.T. et al (2012). Breasfeeding Knowledge and Attitude amongst Health Workers in a health Care Facility in South - South Nigeria : the need for middle level health manpower development. Clinics in Mother and Child Health, International of Nursing Midwifery 9(2012)1-5.

Yuliarti, N (2010) Keajaiban ASImakananan terbaik untuk kesehatan, kecerdasan dan 
kelincahan si kecil. Yogyakarta:ANDI.

Zafar, S.N \& Gavino, M.I.B, (2008) Breasfeeding and working full time, Experince of nurse mother in Karachi, Pakistan. International Juornal of Caring Science, 1(3), 132-139 